\title{
Plant Communities and Floristic Composition of the Vegetation of Wadi Al-Assiuty and Wadi Habib in the Eastern Desert, Egypt
}

\author{
Fawzy M. SALAMA*, Suzan A. SAYED, Ayat A. ABD EL-GELIL \\ :Assiut University, Faculty of Science, Botany Department, Egypt; fawzy_salama2010@yahoo.com (*corresponding author)
}

\begin{abstract}
Torrential rains (in January 2011) that have swept a limited area in the Eastern Desert, facing Assiut Province (Upper Egypt), resulted in enriching the vegetation in Wadi Al-Assiuty and its tributary Wadi Habib. Vegetation survey carried out shortly after this event (in May) revealed the prevalence of annuals which are hardly recognizable in such usually dry habitats. The normally scarce perennial vegetation has flourished. A total of 66 plant species, 33 perennials and 33 annuals, belonging to 53 genera from 22 different families were recorded. Therophytes are the predominant life form (50\%) followed by chamaephytes (21\%), phanerophytes (15\%), hemicryptophytes (11\%) and geophytes (3\%). Chorological analysis revealed that Saharo-Arabian (81.8\%) constitute the main bulk of the total flora of the studied area. The majority of the perennial species behave similarly to each other in their phenology, and usually perennials sprout at the end of February, become leafy in March, flower in April and produce fruits between April and July. The investigation revealed that the wadis studied are potential shelters of four vegetation groups. Twenty two of the recorded species (33.3\%) are omnipresent and had a dominant degree of occurrence (Q-value $\geq 0.2$ ). The highest among others were Zilla spinosa and Zygophyllum coccineum which recorded in $86 \%$ and $88 \%$ respectively of the studied stands and spread their dominancy all over the Eastern Desert of Egypt.
\end{abstract}

Keywords: chorology, cluster analysis, life forms, phenology, phytosociology

\section{Introduction}

The Eastern Desert of Egypt extends between the Nile Valley and the Red Sea. It is traversed by numerous canyonlike depressions (wadis) running to the Red Sea or to the Nile Valley. Wadi Al-Assiuty is one of the most notable features of the Egyptian Eastern Desert. It is the largest and greatest dry valley which runs in Sahara desert for a distance of about $115 \mathrm{~km}$. Its width varies from 5 to $25 \mathrm{~km}$. Although this wadi is generally dry all over the year, some seasonal rainfall is experienced in winter time, which may occasionally become torrential in autumn and spring times.

From the early beginnings of the last century, the Eastern Desert was studied botanically by different researchers: Schweinfurth (1901), Montasir (1938), Hassib (1951), Girgis (1965), Kassas (1953 a,b), Hassan (1987), Salama and Fayed (1989, 1990), Salama and El-Naggar (1991), Abd El-Ghani (1998) and Hassan (2003), Salama et al. (2012, 2013). Except that of Hassan (1987), most of the previous studies dealt with the different ecological aspect, with less attention to the floristic features of this desert.

The main trunk of wadi Al-Assiuty has an east-west orientation extending between latitude $27^{\circ} 10^{\prime}$ and $27^{\circ} 20^{\prime}$ $\mathrm{N}$. Its tributaries cover an area between longitudes $31^{\circ} 16^{\prime}$ and $31^{\circ} 50^{\prime} \mathrm{E}$ (Fig. 1). The main wadis, which debouch their water in wadi Al-Assiuty are: wadi Hubara, wadi Qird ElFarr from north and wadi Marahil, wadi Habib from the south (Said, 1962; Abu Al-Izz, 1971). Due to the variety of chances of water feeding of the tributaries of Wadi Al-
Assiuty originating in the mountain range of Red Sea and pouring their flood waters into its principle channels, difference in floral characteristics and vegetation composition are something expectable. Kassas and Girgis (1972) studied the ecology of Wadi Al-Assiuty among other wadis in the region between latitude $27^{\circ} 30^{\prime}$ and $25^{\circ} 30^{\prime} \mathrm{N}$. Abd El-Wahab (1963) studied the Autecology of Leptadenia pyrotechnica in wadi Al-Assiuty. Migahid et al. (1972) and Batanouny (1973) investigated Eco-Phsiological characters of desert plants in Wadi Al-Assiuty. El-Khatib (1993) studied the ecophysiology and palynology of the vegetation of wadi Al-Assiuty and Wadi Qena based on recent floristic investigations by the author.

Phenological studies provide information on functional rhythms of plants and plant communities (Ralhan et al., 1985). Moreover, various phenological events may be timed to biotic and/or abiotic environmental conditions (Estabrook et al., 1982; Lee, 1971). It was also reported by Nilsen (1981) that desert plants exhibit phenologies that are closely related to moisture availability and temperature, as well as photoperiod and nutrient input (Abdel- Razik, 1980). The phenological cycles may represent physiological and morphological adaptations by species to utilize resources (Kemp and Gardetto, 1982; Salama et al., 2012).

In last decades, Wadi Al-Assiuty was affected by human activities including; cultivation of the deltaic part, the intensive collection of plant species for its values (medicinal, fuel, fiber etc.), establishment of new Assiut city, new high 
ways, farms and others. These activities affect the natural flora and changing the distribution of plants in Wadi AlAssiuty. This means great changes in the distribution, species richness and extinction of the floristic composition of Wadi Al-Assiuty.

Torrential rains (in January 2011) that had suddenly swept a limited area in the Eastern Desert facing Assiut Province (Upper Egypt) resulted in enriching the vegetation of some extremely dry wadis at this location. This leads to the prevalence of annuals and the flourishing of the scarced perennial vegetation (El-Sharkawi et al., 1982 a, b; Salama et al., 2013). It is worthy to mention that the last torrent sudden in this wadi was at 1994 . This reflects the high aridity in the studied wadis.

Such an event was the inspiration to carry out this study with the aim of recognizing the potential of natural vegetation in the wadis as a result of an unexpected water supply. The plant communities and its associated species were investigated. This study deals with analyses of floristic composition, life forms, phenology, chorological spectrum, and analyses the vegetation inhabiting the deltaic part and the principal channel of Wadi Al-Assiuty and Wadi Habib.

\section{Materials and methods}

Wadi Al-Assiuty is easily traversable by vehicle. The study was carried on two successive years: 2011-2012. The studied stands were randomly chosen at locations where considerable vegetation cover was encountered. Based on presence/absence of each species, 50 stands were studied in the deltaic part, and along the main trunk of the Wadi AlAssiuty and Wadi Habib, and geo-referenced using GPS technique (Fig. 1). Meteorological data obtained from the Assiut University station at Assiut, through the last ten years (2003 to 2012) showed the temperature is regular in its seasonality. The average lowest minimum temperature through the last ten years is $8{ }^{\circ} \mathrm{C}$ recorded in January and the average highest maximum temperature is $39{ }^{\circ} \mathrm{C}$ recorded in June. The highest mean relative humidity in the study area is $50 \%$ recorded in December and the lowest mean is $24 \%$ recorded in May.

Ten species were selected randomly to study their phenological characteristics through one year, from January

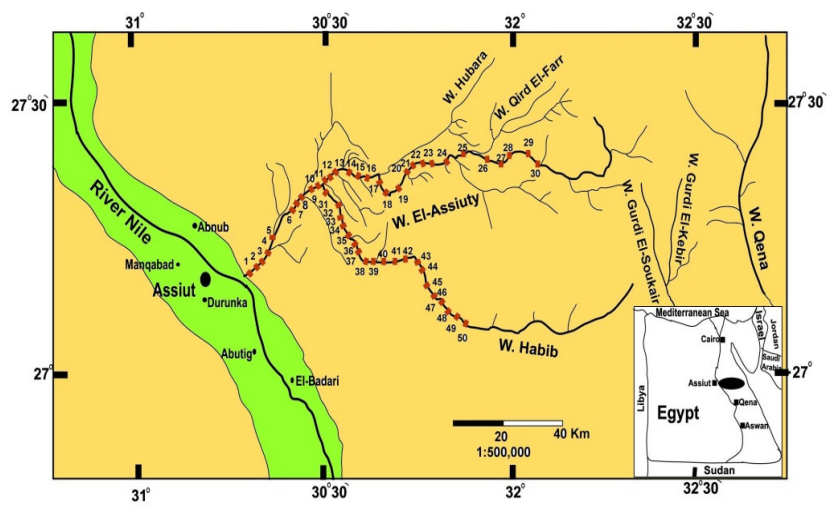

Fig. 1. Location map of Wadi Al-Assiuty and Wadi Habib in the Eastern Desert of Egypt; the stands are given by their numbers
2012 to December 2012. The species were Acacia niotica, Acacia raddiana, Calotropis procera, Datura innoxia, Leptadenia pyrotechnica, Ochradinus baccatus, Tamarix aphylla, Tamarix nilotica, Zizyphus spina-christi and Zygophyllum coccineum. Four phenophases were distinguished: vegetative, flowering, fruiting and seed dispersal and were recorded monthly. The recorded species are classified according to their life forms (Hassib, 1951; Raunkiaer, 1937). The number of species within each life form is expressed as a percentage of the total number of species in the study area. Plant specimens collected were identified and deposited at the herbarium of the Botany Department of Assiut University. Identifications were done according to Täckholm (1974) and Boulos (1995, 1999, 2000). Duplicates were checked for identification and deposited at the Cairo University Herbarium. Analysis of phytogeographical ranges was carried out according to Zohary (1966, 1972, 1973), Abd El-Ghani (1981) and Hassan (1987). A floristic data matrix of 50 stands and 66 species was subjected to classification by cluster analysis of the program Community Analysis Package (CAP) version 1.2 (Henderson and Seaby, 1999) using squared Euclidean distance dissimilarity matrix with minimum variance (also called Ward's method) as agglomeration criterion (Orlóci, 1978).

\section{Results and discussion}

\section{Floristic composition}

The floristic composition of the species showed that 66 plant species were recorded in Wadi El-Assiuty and Wadi Habib. They include 33 perennials and 33 annuals, belonging to 53 genera from 22 different families (Tab. 1). The largest family was Asteraceae, which included 11 genera and 14 species. Six of them were perennials and the others were annuals (Tab. 1). The second family was Chenopodiaceae with six genera and eight species. Four of them were annuals and four were perennials. Brassicaceae, Boraginaceae and Zygophyllaceae had the same number of the recorded species (five for each). Family Brassicaceae included one perennial and four annuals. Family Boraginaceae have two perennial and three annuals. Family Zygophyllaceae included four perennials and one annual. Two genera and four species were recorded for family Fabaceae. Three of them were annuals and one was perennial. Four species were recorded as members of the Poaceae family. They were included in four genera. All of them were perennials except Avena sterilis, which was annual. For each of the Malvaceae, Polygonaceae, Resedaceae, Solanaceae, Mimosaceae, Tamaricaceae families two (for each) species were recorded. One genera belonged to family Tamaricaceae, was represented by two perennial species, Tamarix aphylla and Tamarix nilotica. One genera belonged to Mimosaceae family represented by two perennial species: Acacia nilotica and Acacia tortilis. The other families were represented by only one species, each. The largest genera were: Astragalus, Fagonia and Pulicaria, which include three species. Six genera, represented by two species: Launaea, Bassia, Helliotropium, Chenopodium, Acacia and Zygophyllum. Other genera were represented by one species, each (Tab. 1). 
198

\section{Life form}

Fig. 2 shows the life forms of the recorded plant species according to Raunkiaer (1937). The total number of species in the study area was 66, which belong to five different life forms. Therophytes $(50 \%)$ constitute the largest number of species (33 species). Chamaephytes had $21 \%$ including 14 species. Phanerophytes have 10 species represent about $15 \%$ of the flora. Hemicryptophytes represent about $7 \%$ of the flora including 11 species. Geophytes (3\%) are represented by two species; Cynodon dactylon and Panicum turgidum.

\section{Chorological affinities}

Results of the total chorological analysis of the surveyed flora presented in Fig. 2 revealed that 28 species belonging to monoregional region representing $42.4 \%$ of the total recorded species. There were 26 species recorded as SaharoArabian species (39\%); while Hibiscus trionum belonging to Irano-Turanian region (2\%) and Ammi majus belonging to Mediterranian region (2\%). A total of 28 species are biregional elements representing $42.4 \%$ of the recorded species. It comprises the following four regions as followes: nine species belonging to the Saharo-Arabian, Sudano-Zambezian regions representing $14 \%$ of the recorded species. Mediterranian, Irano-Turanian regions, represented by five species, formed $8 \%$ of the recorded species. Ten species, belonging to the Saharo-Arabian, Irano-Turanian regions represented $15 \%$ of the recorded species. Four species belonging to the Saharo-Arabian, Mediterranian region consist $6 \%$ of the recorded species. A total of five species (7.6\% of the recorded species) are Pluri-regional taxa of wide geographical range. They were as follows: Centaurea calcitrapa, Imperata cylinderica, Matthiola longipetala, Tamarix aphyllaand Tamarix nilotica. Cynodon dactlyon is the only species representing pantropic floristic region. Four species were recorded as cosmopolitan taxa comprising $6.1 \%$ of the recorded species.

\section{Species distribution pattern}

Data of Tab. 1 revealed that four of the recorded species are omnipresent. Zygophyllum coccineum has presence value equal $88 \%$ and recorded in 44 studied stands in the study area. Zilla spinosa was recorded in 43 stands of 50 studied stands giving presence value $86 \%$. Calligonum polygonoides has presence value $74 \%$ and recorded in 37 stands. Cornulaca monacantha was recorded in 35 stands giving presence value $70 \%$.On the other hand, Matthiola longipetala, Atriplex halimus and Cotula cinarea showed the highest presence estimated among annuals $(\mathrm{P}=68 \%, 60 \%$ and 56\%) respectively. Matthiola longipetala appeared in 34 stands, where Atriplex halimus appeared in 30 stands and Cotula cinarea was detected in 28 stands. Artemisia judaica and Eremobium aegyptiacum appeared in 27 stands giving $\mathrm{P}=54 \%$. Diplotaxis acris and Tamarix nilotica recorded in 26 stands (P=52\%). Fagonia arabica and Bassia indica presented in 23 stands $(\mathrm{P}=46 \%) .33$ species or about $50 \%$ of the total recorded species are perennials, demonstrated a constant degree of constancy, while the other 33 species, 50\% of the total recorded species, are annuals most of them recorded after 2011 rainfall. The presence of Tamarix aphylla, Tamarix nilotica, Salsola imbricata and Atriplex halimus refers to salinization.

\section{Phenological pattern}

As shown in Fig. 3, Acacia nilotica started the vegetative growth from July to October. Flowering is in October to December period. The plant began fruiting in January to 'May. In about six months from January to June, Tamarix aphylla completes its vegetative growth. Flowering occurs in two months; July and August. Fruiting takes two months also; September and October. Finally seed dispersal occurs in November and December. Tamarix nilotica grows vegetatively from March to August. Flowering occurs in two months from September to October. Fruiting occurs in two months; November and December, seed dispersal in January and February. Zizyphus spina-christi grows vegetative from August to September. Flowering starts in October to mid of November. Fruiting starts in late of

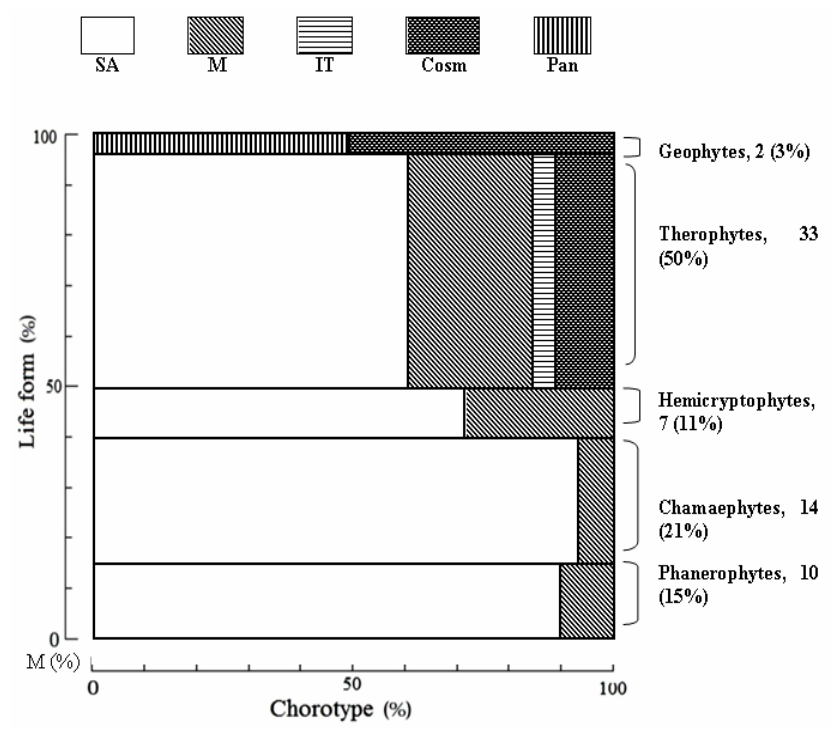

Fig. 2. Chorotype spectrum and life forms diagram of the study area. $\mathrm{SA}=$ Saharo Arabian, $\mathrm{M}=$ Mediterranean, $\mathrm{IT}=$ Irano Toranian, Cosm $=$ Cosmopolitan, $\operatorname{Pan}=$ Pantropic (Kürschner, 1986)

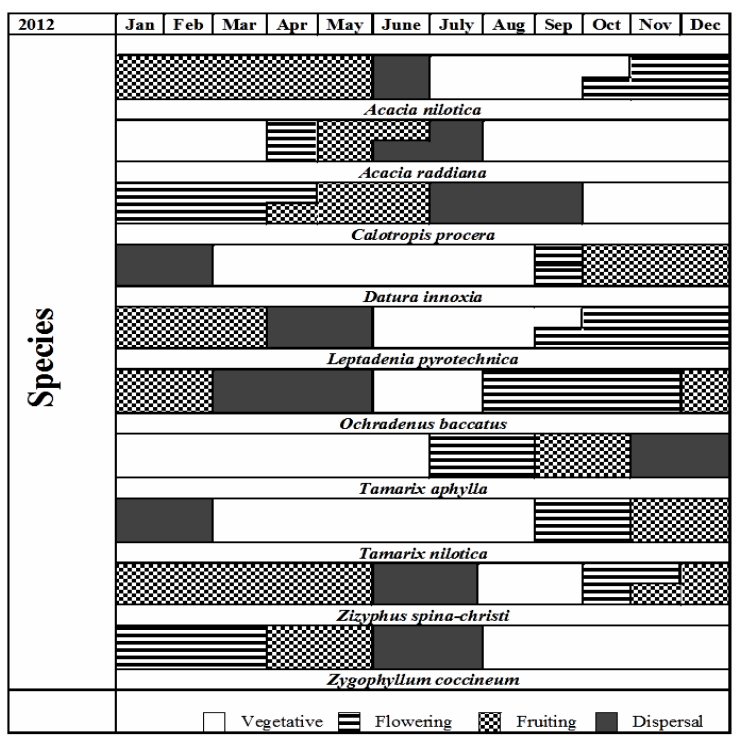

Fig. 3. Phenological spectrum of selected ten species from the study area of wadi El-Assuity during 2012 
November to May. Seed dispersal occurs in June and July. Zygophyllum coccineum starts its vegetative growth from August to December. Flowering occurs from January to March. Fruiting takes two months, from April to May. Seed dispersal occurs after fruiting and lasts to July.

\section{Species Occurrence}

The recorded plants were categorized according to the $Q$ values (Tab. 1) as dominant species: twenty two of the recorded species (33.3\%) are omnipresent had a dominant degree of occurrence ( $Q$-value $\geq 0.2)$. $Q$ values ranged between $0.88-0.20$. Very common species: the very common species generally had $Q$ values ranged between 0.1 0.199 . In this study, twelve species were recorded belonging to this range $(17.9 \%$ of the recorded species $\mathrm{Q}=0.10-0.18)$. Common species: according to $Q$ value calculation ( $Q$ value ranged between 0.05-0.099) there were 5 common species. Helliotropium bacciferum, Kickxia aegyptiaca, Schouwia purpureaandTrigonella stellata were collected from four stands $(\mathrm{Q}=0.08)$, while Astragalus vogelii were collected from three stands $(\mathrm{Q}=0.06)$. $\mathrm{Q}$ value ranged between 0.08 0.06 . Occasional species: most of the recorded species $(28$ species, $41.8 \%$ of total species number) were represented according to $\mathrm{Q}$ value as occasional ( $\mathrm{Q}$ value ranged between $0.01-0.05)$. These plants had presence value was about $4 \%$ $(\mathrm{Q}=0.04)$, while Acacia nilotica, Achillea fragrantissima, Amberboa lippii, Ammi majus, Arnebia hispidissima, Astragalus hamosus, Astragalus sieberi, Avena sterilis, Calotropis procera,Chenopodium ambrosioides, Cynodon dactylon, Datura innoxia, Echium rauwolfii, Hibiscus trionum, Hyoscyamus muticus, Ifloga spicata, Imperata cylinderica, Lactuca serriola, Panicum turgidum and Zizyphus spina-christi were recorded in one stands $(\mathrm{P}=2 \%$ and $\mathrm{Q}=0.02$ ). The sporadic species ( $\mathrm{Q}$-value $\leq 0.01$ ) were not represented in this work.

Vegetation structure (Classification of vegetation)

Application of classification using cluster analysis to the floristic data of Wadi El-Assuity yielded four vegetation groups (Fig. 4). Most of the groups (A) and (B) stands were confined to the main trunk of Wadi El-Assuity, while those of groups (C) and (D) were belonging to the Wadi ElAssuity tributary (Wadi Habib). The Artemisia judaica, Bassia indica, Cotula cinerea, Diplotaxis acris, Eremobium aegyptiacum, Fagonia arabic, Launaea nudicaulis, Leptadenia pyrotechnica, Matthiola longipetala, Pulicaria undulate, Salsola imbricate, Senecio glaucus, Tamarix nilotica, Trichodesma africanum, Zilla spinosaand Zygophyllum coccineum were recorded with variable presence values in the four groups.

Group (A): Senecio glaucus-Zygophyllum coccineum group; this vegetation group comprised of 39 species recorded from 6 stands (Tab. 2). Sporadic species (species recorded in one stand only; $\mathrm{P}$ (presence value) $=17 \%$ ) were represented by 18 species or about $46.2 \%$ of the recorded species in this group and they were; Acacia nilotica, Achillea fragrantissima, Ammi majus, Anabasis setifera, Artemisia judaica, Calotropis procera, Cynodon dactylon, Datura innoxia, Fagonia arabica, Hibiscus trionum, Hyoscyamus muticus, Imperata cylinderica, Launaea amal-aminae,
Ochradinus baccatus, Oligomeris linifolia, Rumex vesicarius, Trichodesma africanum and Zizyphus spina-christi. While Launaea nudicaulis and Tamarix nilotica show codominance with a presence value $67 \%$ (were represented by two species or about $5.1 \%$ of the recorded species in this group) (Tab. 2). The 12 species represent $30.8 \%$ of this group plants: Acacia nilotica, Achillea fragrantissima, Ammi majus, Calotropis procera, Chenopodium murale, Cynodon dactylon, Datura innoxia, Hibiscus trionum, Hyoscyamus muticus, Imperata cylinderica, Zizyphus spina-christi and Zygophyllum simplex had a degree of fidelity to this community.

Group (B): Zilla spinosa-Zygophyllum coccineum group. It comprised of 49 species recorded in 14stands (Tab. 2). The 24 sporadic species ( $49 \%$ of the recorded species in this group; P=7-14\%) were: Acacia tortilis, Amberboa lippii, Anabasis setifera, Arnebia bispidissima, Astragalus hamosus, Avena sterilis, Centaurea calcitrapa, Chenopodium ambrosioides, Cleome amblyocera, Echium rauwolfii, Helliotropium bacciferum, Ifloga spicat, Kickxia aegyptiaca, Lactuca serriola, Leptadenia pyrotechnica, Pulicaria incis, Schouwia purpurea, Artemisia judaica, Fagonia bruguieri,

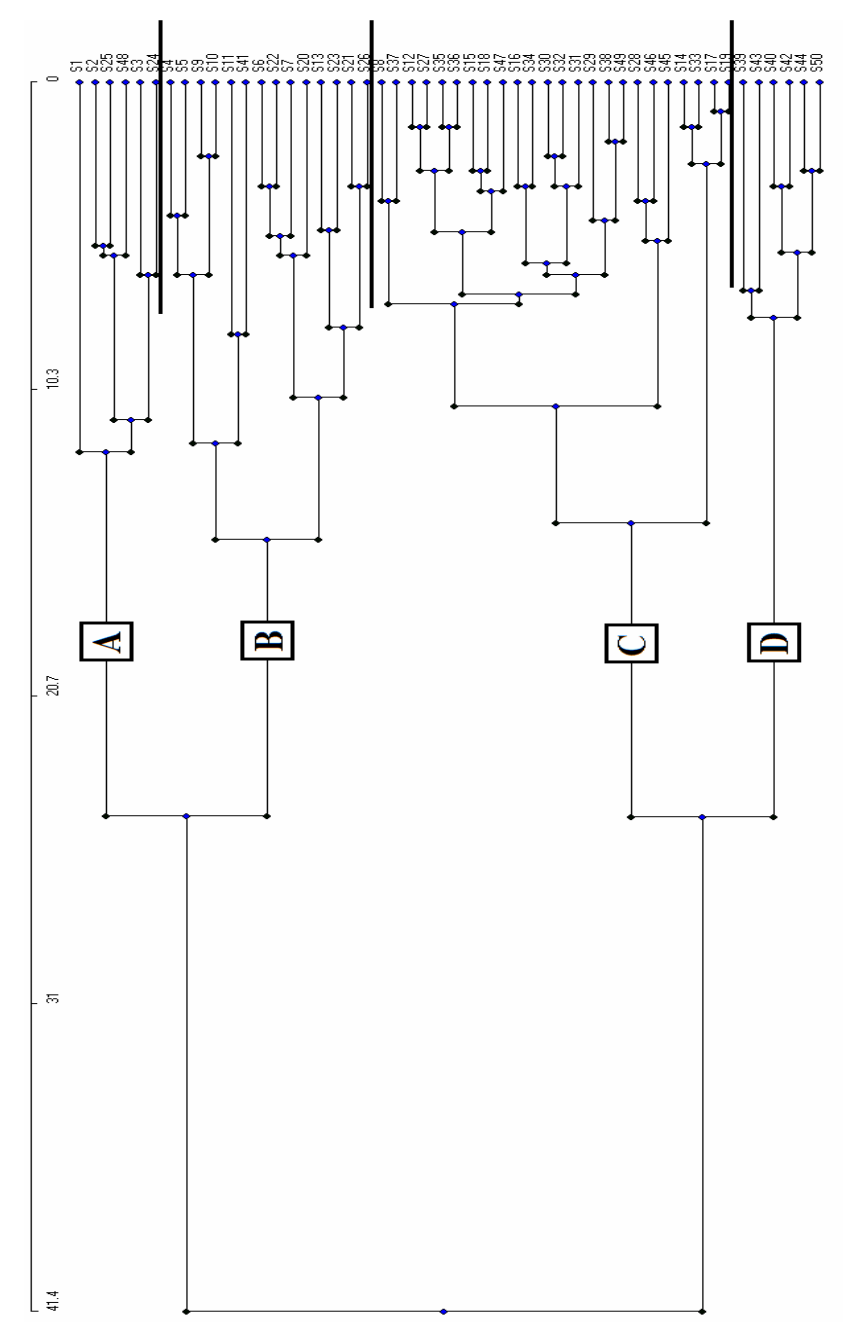

Fig. 4. Dendrogram showing cluster analysis of the studied 50 stands with the 4 vegetation groups (A-D) in Wadi El-Assuity and Wadi Habib 
200

Launaea nudicaulis, Monsonia nivea, Sonchus oleraceus,Tamarix aphylla and Tamarix nilotica. WhileDiplotaxis acris ( $\mathrm{P}=93 \%)$, Fagonia arabica $(\mathrm{P}=86 \%)$, Atriplex halimus $(\mathrm{P}=86 \%)$, Cornulaca monacantha ( $\mathrm{P}=86 \%)$, Cotula cinerea ( $\mathrm{P}=71 \%)$, Matthiola longipetala $(\mathrm{P}=71 \%)$, Senecio glaucus $(\mathrm{P}=71 \%)$, Rumex vesicarius $(\mathrm{P}=71 \%)$, Salsola imbricate $(\mathrm{P}=64 \%)$ represented as codominance species (18.4\% of this group species). The following 10 species (20.4\% of plants in this group) showed a degree of fidelity to this community and they were; Amberboa lippii, Arnebia hispidissima, Astragalus hamosus, Astragalus vogelii, Avena sterilis, Chenopodium ambrosioides, Echium rauwolfii, Ifloga spicata, Lactuca serriola and Monsonia nivea.

Group (C): Calligonum polygonoides-Zilla spinosa group. The species belonging to this group were 33 species in 24 stands (Tab. 2) with 17 sporadic species (about 51.5\% of the recorded species in this group; $\mathrm{P}=4-17 \%$ ) and they were Bassia muricata, Pulicaria arabica, Trichodesma africanum, Centaurea calcitrapa, Helliotropium bacciferum, Tamarix aphylla, Senecio glaucus, Pulicaria incise, Launaea nudicaulis, Launaea amal-aminae, Salsola imbricate, Malva parviflora, Oligomeris linifolia, Ochradinus baccatus, Acacia tortilis, Paronychia arabica, and Panicum turgidum. The codominance species were 7 species represent $21.2 \%$ of plant in this group $(\mathrm{P}=63-88 \%)$. They were Zilla spinosa, Zygophyllum coccineum, Eremobium aegyptiacum, Artemisia judaica, Cornulaca monacantha, Matthiola longipetala and Tamarix nilotica. Only Panicum turgidum showed a degree of fidelity.

Group (D): Artemisia judaica-Matthiola longipetala group. This vegetation group comprised of 31 species recorded from six stands (Tab. 2). This group included five characteristic species: Zilla spinosa, Atriplex halimus, Calligonum polygonoides and Pulicaria incisahad the dominance degree $(\mathrm{P}=100 \%)$ with Artemisia judaica and Matthiola longipetala. Sporadic species (species recorded in one stand only; $\mathrm{P}=17 \%$ ) were represented by six species or about $19.4 \%$ of the recorded species in this group: Astragalus sieberi, Cleome amblyocera, Fagonia arabica, Launaea nudicaulis, Trichodesma africanum and Trigonella stellate. The co-dominant species were represented by 11 species with $35.5 \%$ of plant in this group. Seven species had presence value of $83 \%$ (Bassia indica, Centaurea calcitrapa, Cornulaca monacantha, Fagonia bruguieri, Leptadenia pyrotechnica, Tamarix nilotica and Zygophyllum coccineum); four species had presence value 67\% (Diplotaxis acris, Pulicaria undulate, Rumx vesicarius and Salsola imbricate). Two species Astragalus sieberi and Helliotropium digynum had a presence value of $17 \%, 33 \%$ with fidelity of degree.

The present study comprises an ecological survey in Wadi Al-Assiuty and its tributary Wadi Habib in the Eastern Desert of Egypt. The impact of extreme aridity and the scanty rains in Wadi Al-Assiuty and its tributaries is quite clear from the poverty of species encountered. The plant species collected from the study area of Wadi AlAssiuty included 66 species, 33 perennials and 33 annuals, belonging to 53 genera from 22 different families. Most of the collected annuals were recorded after 2011 rainfalls. The largest family was Asteraceae which represented by 14 species $(21.2 \%$ of the recorded species), followed by family Chenopodiaceae which represented by eight species (12.1\%). It may be noted that the deltaic part of Wadi AlAssiuty and a great part of its main course are parts of a great bay fringing the Nile Valley. The near of underground water reservoir from the surface in this area, at depth $2-5 \mathrm{~m}$ (Kassas and Girgis, 1972) is obviously an important source of water for plants with deep roots (perennials).

Taking into account the Q-values of the recorded species, twenty two of the recorded species (33.3\%) are omnipresent and had a dominant degree of occurrence (Qvalue $\geq 0.2$ ). $Q$ values ranged between $0.88-0.20$ (Tab. 1 ). The highest among others were Zilla spinosa and Zygophyllum coccineum which recorded in $86 \%$ and $88 \%$ respectively of the studied stands and spread their dominancy all over the Eastern Desert of Egypt. Their dominance over the communities of the Eastern Desert was documented by many scientists: Montasir (1938), Hassib (1951), Kassas and Imam (1954), Kassas and El-Abyad (1962), Kassas and Girgis (1964), Salama and El-Naggar (1991), Abd El-Ghani (1998) and Galal and Fahmy (2012). Fossati et al. (1998) recorded Zilla spinosa and Zygophyllum coccineum and indicated their wide range of distribution, often on fine calcareous neutral or alkaline substratum. The remaining dominant species showed a regional dominancy over certain sectors. The very common species generally had $Q$ values ranged between 0.1-0.199. In this study, twelve species were recorded belonging to this range (17.9\% of the recorded species $\mathrm{Q}=0.10-0.18)$. According to $\mathrm{Q}$ value calculation ( $Q$ value ranged between 0.05-0.099) there were five common species. Helliotropium bacciferum, Kickxia aegyptiaca, Schouwia purpurea and Trigonella stellata were collected from four stands $(\mathrm{P}=8 \% ; \mathrm{Q}=0.08)$, while Astragalus vogelii were collected from three stands $(\mathrm{P}=6 \%$; $\mathrm{Q}=0.06)$. $\mathrm{Q}$ value ranged between $0.08-0.06$. Occasional species were represented by 28 species such as Acacia nilotica, Achillea fragrantissima, Amberboa lippii, Ammi majus, Arnebia hispidissima, Astragalus hamosus, Astragalus sieberi, Avena sterilis, Calotropis procera, Chenopodium ambrosioides, Cynodon dactylon, Datura innoxia, Echium rauwolfi, Hibiscus trionum, Hyoscyamus muticus, Ifloga spicata, Imperata cylinderica, Lactuca serriola, Panicum turgidum and Zizyphus spina-christi were in one stands $(\mathrm{P}=2 \%$ and $\mathrm{Q}=0.02)$. The sporadic species $(\mathrm{Q}$-value $\leq 0.01)$ were not represented in this work. Zygophyllum coccineum, Zilla spinosa and Calligonum polygonoides have the highest presence values in Wadi Al-Assiuty. The same species were identified in other wadis in the Eastern Desert as members of the alliance Zygophyllaeion (Salama and Fayed, 1990). Calligonum polygonoides has an analogue and previously recognized in Wadi El-Miyah (El-Sharkawi et al., 1982b). Salama and Fayed (1989) recognized Zilla spinosa and Salsola imbricata in one community in Wadi Barramiya. Zilla spinosa has also been recorded in the wadi system west of Qusseir province (Salama and El-Naggar, 1991); Wadi El-Matuli, Wadi Gimal, Wadi Qassab (El-Sharkawi et al., 1982a, 1982b, 1984) Wadi Kherit and Wadi El-Ghuza (ElSharkawi et al., 1987, 1988). The 33 collected annual species ( $50 \%$ of total flora) in the present study may be 
Tab. 1. Species composition of the study area classified according to the different families, together with their presence values ( $\mathrm{P} \%)$, chorology and occurrences. Choro=Chorology (SA=Saharo-Arabian, SZ=Sudano-Zambezian, $\mathrm{M}=$ Mediterranean, $\mathrm{IT}=\mathrm{Irano}-\mathrm{Turanian}, \mathrm{Cosm}=\mathrm{Cosmopolitan}, \mathrm{Pan}=$ Pantropical). $\mathrm{Q}=$ Occurrence $(\mathrm{D}=$ Dominant, VC=Very common, $\mathrm{C}=$ Common, $\mathrm{O}=$ Occasional, $\mathrm{S}=$ Sporadic); L.F.=Life forms (Th: Therophytes, He: Hemicryptophytes, Ch: Chamaephytes, G=Geophytes and Ph: Phanerophytes; Dur.=Duration (Ann.=Annual and Per.=Perennial)

\begin{tabular}{|c|c|c|c|c|c|}
\hline Families and species & Dur. & L.F & Choro. & $\mathrm{P} \%$ & Q \\
\hline $\begin{array}{c}\text { Apiaceae } \\
\text { Ammi majus } \mathrm{L} .\end{array}$ & Ann. & Th & M & 2 & $\mathrm{O}$ \\
\hline $\begin{array}{c}\text { Apocynaceae } \\
\text { Leptadenia pyrotechnica (Forssk.) Decne. }\end{array}$ & Per & $\mathrm{Ph}$ & $S A+S Z$ & 40 & $\mathrm{D}$ \\
\hline $\begin{array}{c}\text { Asclepiadaceae } \\
\text { Calotropisprocera(Aiton) W.T. Aiton }\end{array}$ & Per & $\mathrm{Ph}$ & $\mathrm{SA}+\mathrm{SZ}$ & 2 & $\mathrm{O}$ \\
\hline $\begin{array}{c}\text { Asteraceae } \\
\text { Achillea fragrantissima(Forssk.) Sch. Bip } \\
\text { Amberboa lippii (L.)DC } \\
\text { Artemisia judaica L. } \\
\text { Centaurea calcitrapa L. } \\
\text { Cotula cinerea Delile } \\
\text { Ifloga spicata (Frossk.) Sch. Bip. } \\
\text { Lactuca serriola L. } \\
\text { Launaea amal-aminae (Boiss.) Kuntze } \\
\text { Launaea nudicaulis (L.) Hook. f. } \\
\text { Pulicaria arabica (L.) Cass. } \\
\text { Pulicaria undulata(L.) C. A. My. } \\
\text { Pulicaria incisa (Lam.) DC. } \\
\text { Senecio glaucus L. subsp. coropifolius (Maire) C. Ale } \\
\text { Sonchus oleraceus L. }\end{array}$ & $\begin{array}{c}\text { Per } \\
\text { Ann } \\
\text { Per } \\
\text { Per } \\
\text { Ann } \\
\text { Ann } \\
\text { Ann } \\
\text { Ann } \\
\text { Per } \\
\text { Ann } \\
\text { Per } \\
\text { Per } \\
\text { Ann }\end{array}$ & $\begin{array}{l}\text { Ch } \\
\text { Th } \\
\text { Ch } \\
\mathrm{He} \\
\text { Th } \\
\text { Th } \\
\text { Th } \\
\text { Th } \\
\mathrm{He} \\
\text { Th } \\
\mathrm{He} \\
\mathrm{He} \\
\mathrm{Th}\end{array}$ & $\begin{array}{c}\text { SA+IT } \\
\text { SA+SZ } \\
\text { SA } \\
\text { M+SA+IT } \\
\text { SA } \\
\text { SA+SZ } \\
\text { M+IT } \\
\text { SA } \\
\text { SA+IT } \\
\text { M+SA } \\
\text { SA } \\
\text { SA } \\
\text { SA+IT } \\
\text { Cosm }\end{array}$ & $\begin{array}{c}2 \\
2 \\
54 \\
18 \\
56 \\
2 \\
2 \\
20 \\
16 \\
12 \\
44 \\
18 \\
40\end{array}$ & $\begin{array}{c}\text { O } \\
\text { O } \\
\text { D } \\
\text { VC } \\
\text { D } \\
\text { O } \\
\text { O } \\
\text { D } \\
\text { VC } \\
\text { VC } \\
\text { D } \\
\text { VC } \\
\text { D }\end{array}$ \\
\hline $\begin{array}{c}\text { Boraginaceae } \\
\text { Arnebia hispidissima (Lehm.) DC. } \\
\text { Echium rauwolfii Delile } \\
\text { Helliotropium bacciferum Fross } \\
\text { Helliotropium digynum (Forssk.) C.Chr. } \\
\text { Trichodesma africanum (L.) R. Br. }\end{array}$ & $\begin{array}{c}\text { Ann } \\
\text { Ann } \\
\text { Per } \\
\text { Per } \\
\text { Ann }\end{array}$ & $\begin{array}{l}\text { Th } \\
\text { Th } \\
\text { Ch } \\
\text { Ch } \\
\text { Th }\end{array}$ & $\begin{array}{c}\text { SA } \\
\text { SA } \\
\text { SA } \\
\text { SA } \\
\text { SA+SZ }\end{array}$ & $\begin{array}{c}2 \\
2 \\
8 \\
4 \\
22\end{array}$ & $\begin{array}{l}\mathrm{O} \\
\mathrm{O} \\
\mathrm{C} \\
\mathrm{O} \\
\mathrm{D}\end{array}$ \\
\hline $\begin{array}{c}\text { Brassicaceae } \\
\text { Diplotaxis acris (Forssk.) Boiss. } \\
\text { Eremobiuma egyptiacum (Spreng.) Asch. \&Schweinf } \\
\text { Matthiola longipetala (Vent) DC. } \\
\text { Schouwia purpurea (Forssk.) Schweinf. } \\
\text { Zilla spinosa (L.) Prantl. }\end{array}$ & $\begin{array}{l}\text { Ann } \\
\text { Ann } \\
\text { Ann } \\
\text { Ann } \\
\text { Per }\end{array}$ & $\begin{array}{l}\text { Th } \\
\text { Th } \\
\text { Th } \\
\text { Th } \\
\text { Ch }\end{array}$ & $\begin{array}{l}\text { M+IT } \\
\text { SA } \\
\text { M+SA+IT } \\
\text { SA } \\
\text { SA }\end{array}$ & $\begin{array}{c}52 \\
54 \\
68 \\
8 \\
86\end{array}$ & $\begin{array}{l}\mathrm{D} \\
\mathrm{C} \\
\mathrm{D}\end{array}$ \\
\hline $\begin{array}{c}\text { Caryophyllaceae } \\
\text { Paronychia arabica (L.) DC. }\end{array}$ & Ann & Th & SA & 10 & $\mathrm{VC}$ \\
\hline $\begin{array}{c}\text { Chenopodiaceae } \\
\text { Anabasis setifera Moq. } \\
\text { Atriplex halimus L. } \\
\text { Bassia indica (Wight) A.J.Scott } \\
\text { Bassia muricata (L.) Asch } \\
\text { Chenopodium ambrosioides L. } \\
\text { Chenopodium murale L. } \\
\text { Cornulaca monacantha Delile } \\
\text { Salsola imbricate Forssk. sub sp. imbricate }\end{array}$ & $\begin{array}{l}\text { Per } \\
\text { Per } \\
\text { Ann } \\
\text { Ann } \\
\text { Ann } \\
\text { Ann } \\
\text { Per } \\
\text { Per }\end{array}$ & $\begin{array}{l}\text { Ch } \\
\text { Ph } \\
\text { Th } \\
\text { Th } \\
\text { Th } \\
\text { Th } \\
\text { Ch } \\
\text { Ch }\end{array}$ & $\begin{array}{c}\text { SA } \\
\text { M+SA } \\
\text { SA+IT } \\
\text { SA+IT } \\
\text { Cosm } \\
\text { Cosm } \\
\text { SA } \\
\text { SA+IT }\end{array}$ & $\begin{array}{c}4 \\
60 \\
46 \\
28 \\
2 \\
4 \\
70 \\
32\end{array}$ & $\begin{array}{l}\text { O } \\
\text { D } \\
\text { D } \\
\text { D } \\
\text { O } \\
\text { O } \\
\text { D } \\
\text { D }\end{array}$ \\
\hline $\begin{array}{c}\text { Cleomaceae } \\
\text { Cleom amblyocera Barratte \& Murb. }\end{array}$ & Ann & Th & SA & 4 & $\mathrm{O}$ \\
\hline
\end{tabular}




\begin{tabular}{|c|c|c|c|c|c|}
\hline $\begin{array}{c}\text { Fabaceae } \\
\text { Astragalus hamosus } \mathrm{L} . \\
\text { Astragalus sieberi } \mathrm{DC} . \\
\text { Astragalus vogelii (Webb) Bornm. } \\
\text { Trigonella stellata Forssk. }\end{array}$ & $\begin{array}{l}\text { Ann } \\
\text { Per } \\
\text { Ann } \\
\text { Ann }\end{array}$ & $\begin{array}{l}\text { Th } \\
\text { Ch } \\
\text { Th } \\
\text { Th }\end{array}$ & $\begin{array}{c}\mathrm{M}+\mathrm{IT} \\
\mathrm{SA} \\
\mathrm{SA} \\
\mathrm{SA}\end{array}$ & $\begin{array}{l}2 \\
2 \\
6 \\
8\end{array}$ & $\begin{array}{l}\mathrm{O} \\
\mathrm{O} \\
\mathrm{C} \\
\mathrm{C}\end{array}$ \\
\hline $\begin{array}{c}\text { Geraniaceae } \\
\text { Monsonia nivea (Decne.) Webb }\end{array}$ & Per & $\mathrm{He}$ & SA & 4 & $\mathrm{O}$ \\
\hline $\begin{array}{l}\text { Malvaceae } \\
\text { Hibiscus trionum } \mathrm{L} \text {. } \\
\text { Malva parviflora } \mathrm{L} \text {. }\end{array}$ & $\begin{array}{l}\text { Ann } \\
\text { Ann }\end{array}$ & $\begin{array}{l}\text { Th } \\
\text { Th }\end{array}$ & $\begin{array}{c}\text { IT } \\
\mathrm{M}+\mathrm{IT}\end{array}$ & $\begin{array}{c}2 \\
12\end{array}$ & $\begin{array}{c}\mathrm{O} \\
\mathrm{VC}\end{array}$ \\
\hline $\begin{array}{c}\text { Mimosaceae } \\
\text { Acacia nilotica (L.) Delile } \\
\text { Acacia tortilis (Forssk.) Hayne subsp. raddiana (Savi) Brenan }\end{array}$ & $\begin{array}{l}\text { Per } \\
\text { Per }\end{array}$ & $\begin{array}{l}\mathrm{Ph} \\
\mathrm{Ph}\end{array}$ & $\begin{array}{c}\text { SA } \\
S A+S Z\end{array}$ & $\begin{array}{l}2 \\
4\end{array}$ & $\begin{array}{l}\mathrm{O} \\
\mathrm{O}\end{array}$ \\
\hline $\begin{array}{c}\text { Plantaginaceae } \\
\text { Plantago ciliate Desf. }\end{array}$ & Ann & Th & $\mathrm{SA}+\mathrm{IT}$ & 12 & VC \\
\hline $\begin{array}{c}\text { Poaceae } \\
\text { Avena sterilis } \mathrm{L} . \\
\text { Cynodon dactylon }(\mathrm{L} .) \text { Pers. } \\
\text { Imperata cylinderica }(\mathrm{L} .) \text { Raeusch. } \\
\text { Panicum turgidum Frossk. }\end{array}$ & $\begin{array}{l}\text { Ann } \\
\text { Per } \\
\text { Per } \\
\text { Per }\end{array}$ & $\begin{array}{l}\text { Th } \\
\text { G } \\
\text { He } \\
\text { G }\end{array}$ & $\begin{array}{l}\mathrm{M}+\mathrm{IT} \\
\text { Pan } \\
\mathrm{M}+\mathrm{SA}+\mathrm{IT} \\
\mathrm{M}+\mathrm{SA}\end{array}$ & $\begin{array}{l}2 \\
2 \\
2 \\
2\end{array}$ & $\begin{array}{l}\mathrm{O} \\
\mathrm{O} \\
\mathrm{O} \\
\mathrm{O}\end{array}$ \\
\hline $\begin{array}{l}\text { Polygonaceae } \\
\text { Calligonum polygonoides L'Hèr. } \\
\text { Rumx vesicarius } \mathrm{L} \text {. }\end{array}$ & $\begin{array}{l}\text { Per } \\
\text { Ann }\end{array}$ & $\begin{array}{l}\mathrm{Ph} \\
\mathrm{Th}\end{array}$ & $\begin{array}{l}\mathrm{SA}+\mathrm{IT} \\
\mathrm{SA}+\mathrm{IT}\end{array}$ & $\begin{array}{l}74 \\
30\end{array}$ & $\begin{array}{l}\mathrm{D} \\
\mathrm{D}\end{array}$ \\
\hline $\begin{array}{c}\text { Resedaceae } \\
\text { Ochradinus baccatus Delile } \\
\text { Oligomris linifolia (Hornew) J.F. Macbr. }\end{array}$ & $\begin{array}{l}\text { Per } \\
\text { Ann }\end{array}$ & $\begin{array}{l}\mathrm{Ph} \\
\mathrm{Th}\end{array}$ & $\begin{array}{l}S A+S Z \\
S A+S Z\end{array}$ & $\begin{array}{c}4 \\
18\end{array}$ & $\begin{array}{c}\mathrm{O} \\
\mathrm{VC}\end{array}$ \\
\hline $\begin{array}{c}\text { Rhamnaceae } \\
\text { Zizyphus spina-christi (L.)Desf. }\end{array}$ & Per & $\mathrm{Ph}$ & SA & 2 & $\mathrm{O}$ \\
\hline $\begin{array}{c}\text { Scrophulariaceae } \\
\text { Kickxia aegyptiaca (L.)Na'belek }\end{array}$ & Per & $\mathrm{Ch}$ & $\mathrm{M}+\mathrm{SA}$ & 8 & C \\
\hline $\begin{array}{c}\text { Solanaceae } \\
\text { Datura innoxia Mill. } \\
\text { Hyoscyamus muticus L. }\end{array}$ & $\begin{array}{l}\text { Ann } \\
\text { Per }\end{array}$ & $\begin{array}{l}\text { Th } \\
\text { Ch }\end{array}$ & $\begin{array}{c}\text { Cosm } \\
\text { SA }\end{array}$ & $\begin{array}{l}2 \\
2\end{array}$ & $\begin{array}{l}\mathrm{O} \\
\mathrm{O}\end{array}$ \\
\hline $\begin{array}{c}\text { Tamaricaceae } \\
\text { Tamarix aphylla }(\text { L.) H. Karst. } \\
\text { Tamarix nilotica (Ehreub.) Bunge }\end{array}$ & $\begin{array}{l}\text { Per } \\
\text { Per }\end{array}$ & $\begin{array}{l}\mathrm{Ph} \\
\mathrm{Ph}\end{array}$ & $\begin{array}{l}\mathrm{SA}+\mathrm{SZ}+\mathrm{IT} \\
\mathrm{SA}+\mathrm{SZ}+\mathrm{M}\end{array}$ & $\begin{array}{l}14 \\
52\end{array}$ & $\begin{array}{l}\mathrm{VC} \\
\mathrm{D}\end{array}$ \\
\hline $\begin{array}{c}\text { Zygophyllaceae } \\
\text { Fagonia arabica L. } \\
\text { Fagonia bruguieri DC. } \\
\text { Fagonia indica Burm. } \mathrm{f} \text {. } \\
\text { Zygophyllum coccineum } \mathrm{L} \text {. } \\
\text { Zygophyllum simplex } \mathrm{L} \text {. }\end{array}$ & $\begin{array}{l}\text { Per } \\
\text { Per } \\
\text { Per } \\
\text { Per } \\
\text { Ann }\end{array}$ & $\begin{array}{l}\mathrm{Ch} \\
\mathrm{He} \\
\mathrm{Ch} \\
\mathrm{Ch} \\
\mathrm{Th}\end{array}$ & $\begin{array}{c}\text { SA } \\
\text { SA+IT } \\
\text { SA } \\
\text { SA+SZ } \\
\text { SA }\end{array}$ & $\begin{array}{c}46 \\
18 \\
34 \\
88 \\
4\end{array}$ & $\begin{array}{l}\mathrm{D} \\
\mathrm{VC} \\
\mathrm{D} \\
\mathrm{D} \\
\mathrm{O}\end{array}$ \\
\hline
\end{tabular}

attributed to a heavy rainfall in January 2011.

Plant life forms resulted from evolved adaptation to environment and climate (Kassas, 1955). The life form spectrum of Wadi El-Assiuty (Fig. 2) showed that the proportion of therophytes $(50 \%)$ is higher than that of other life forms, while the proportion of chamaephytes (21\%) and phanerophytes (15\%) are not worthy. High percentages of therophytes and chamaephytes coincide with the floristic characters of the arid zones and semi-arid zones (Bornkamm and Kehl, 1985; Migahid et al., 1971; Pignatti and Pignatti, 1989). Danin and Orshan (1990) pointed out that the life form pattern of the desert plants correlates mainly with rainfall. Life form distribution of the desert plants is also correlated with topography and land form
(Kassas and Girgis, 1965; Orshan, 1986; Zohary, 1973).

Results of the total chorological analysis of the surveyed flora (Fig. 2) revealed that 28 species (42.4\% of the total flora) are mono-regional, of which 26 species (39.4\%) are native to the Saharo-Arabian chorotype. Cosmopolitan ranked second with $3.1 \%$. About $50 \%$ of the recorded species are 33 bioregional and pluri-regional, extending their distribution all over the Saharo-ArabianSudano-Zambezian, Irano-Turanian and Mediterranean regions. The SaharoArabian chorotype (bi- and pluri-), part of the SaharoArabian region, constitutes $34.8 \%$ and $7.6 \%$, respectively, of the recorded species (total 81.8\%) and it forms the major component of the floristic composition of this study. These results coincide with Hassan (1987), Sheded (1992) and 
Tab. 2. Floristic composition in the vegetation groups of Wadi El-Assuity and Wadi Habib. Figures in bold are species with highest presence values

\begin{tabular}{|c|c|c|c|c|}
\hline Groups & A & B & $\mathrm{C}$ & $\mathrm{D}$ \\
\hline No.of stands & 6 & 14 & 24 & 6 \\
\hline No.of species & 39 & 49 & 33 & 31 \\
\hline Bassia indica (Wight) A.J.Scott & 50 & 43 & 38 & 83 \\
\hline Cotula cinerea Delile Ann & 50 & 71 & 54 & 33 \\
\hline Diplotaxis acris (Forssk.) Boiss. & 33 & 93 & 29 & 67 \\
\hline Eremobium aegyptiacum (Spreng.) Asch. \&Schweinf. ex Bioss & 33 & 36 & 75 & 33 \\
\hline Fagonia arabica L. & 17 & 86 & 38 & 17 \\
\hline Launaea nudicaulis (L.) Hook. f. & 67 & 14 & 4 & 17 \\
\hline Leptadenia pyrotechnica (Forssk.) Decne. & 50 & 7 & 46 & 83 \\
\hline Matthiola longipetala (Vent) DC. & 50 & 71 & 63 & 100 \\
\hline Pulicaria undulata(L.) C. A. My. & 33 & 36 & 46 & 67 \\
\hline Salsola imbricata Forssk. & 33 & 64 & 4 & 67 \\
\hline Senecio glaucus L. subsp. coropifolius (Maire) C. Alexander Ann & 100 & 71 & 8 & 33 \\
\hline Tamarix nilotica (Ehreub.) Bunge & 67 & 14 & 63 & 83 \\
\hline Trichodesma africanum (L.) R. Br. & 17 & 43 & 13 & 17 \\
\hline Zilla spinosa (L.) Prantl. & 33 & 100 & 88 & 100 \\
\hline Zygophyllum coccineum $\mathrm{L}$. & 100 & 100 & 79 & 83 \\
\hline Artemisia judaica $\mathrm{L}$. & 17 & 14 & 75 & 100 \\
\hline Bassia muricata (L.) Asch Ann & 50 & 50 & 17 & \\
\hline Fagonia indica Burm. f. & 50 & 57 & 25 & \\
\hline Launaea amal-aminae N. Kilian & 17 & 57 & 4 & \\
\hline Malva parviflora $\mathrm{L}$. & 33 & 21 & 4 & \\
\hline Oligomeris linifolia (Vahl.) ex Hornew J. F. Macbr. & 17 & 50 & 4 & \\
\hline Fagonia bruguieri DC. & 33 & 14 & & 83 \\
\hline Rumx vesicarius $\mathrm{L}$. & 17 & 71 & & 67 \\
\hline Anabasis setifera Moq. & 17 & 7 & & \\
\hline Schouwia purpurea (Forssk.) Schweinf. & 50 & 7 & & \\
\hline Sonchus oleraceus $\mathrm{L}$. & 50 & 14 & & \\
\hline Ochradinus baccatus Delile & 17 & & 4 & \\
\hline Acacia nilotica (L.) Delile & 17 & & & \\
\hline Achillea fragrantissima (Forssk.) Sch. Bip & 17 & & & \\
\hline Ammi majus L. & 17 & & & \\
\hline Calotropis procera(Aiton) W. T. Aiton & 17 & & & \\
\hline Chenopodium murale $\mathrm{L}$. & 33 & & & \\
\hline Cynodon dactylon (L.) Pers. & 17 & & & \\
\hline Datura innoxia Mill. & 17 & & & \\
\hline Hibiscus trionum $\mathrm{L}$. & 17 & & & \\
\hline Hyoscyamus muticus $\mathrm{L}$. & 17 & & & \\
\hline Imperata cylinderica (L.) Raeusch. & 17 & & & \\
\hline Zizyphus spina-christi (L.)Desf. & 17 & & & \\
\hline Zygophyllum simplex $\mathrm{L}$. & 33 & & & \\
\hline Atriplex halimus $\mathrm{L}$. & & 86 & 50 & 100 \\
\hline Calligonum polygonoides L'Hèr. & & 50 & 100 & 100 \\
\hline Centaurea calcitrapa $\mathrm{L}$. & & 7 & 13 & 83 \\
\hline Cornulaca monacantha Delile & & 86 & 75 & 83 \\
\hline Pulicaria incisa (Lam.) DC. & & 7 & 8 & 100 \\
\hline Tamarix aphylla (L.) H. Karst. & & 14 & 13 & 33 \\
\hline Acacia tortilis (Forssk.) Hayne subsp. raddiana (Savi) Brenan & & 7 & 4 & \\
\hline
\end{tabular}




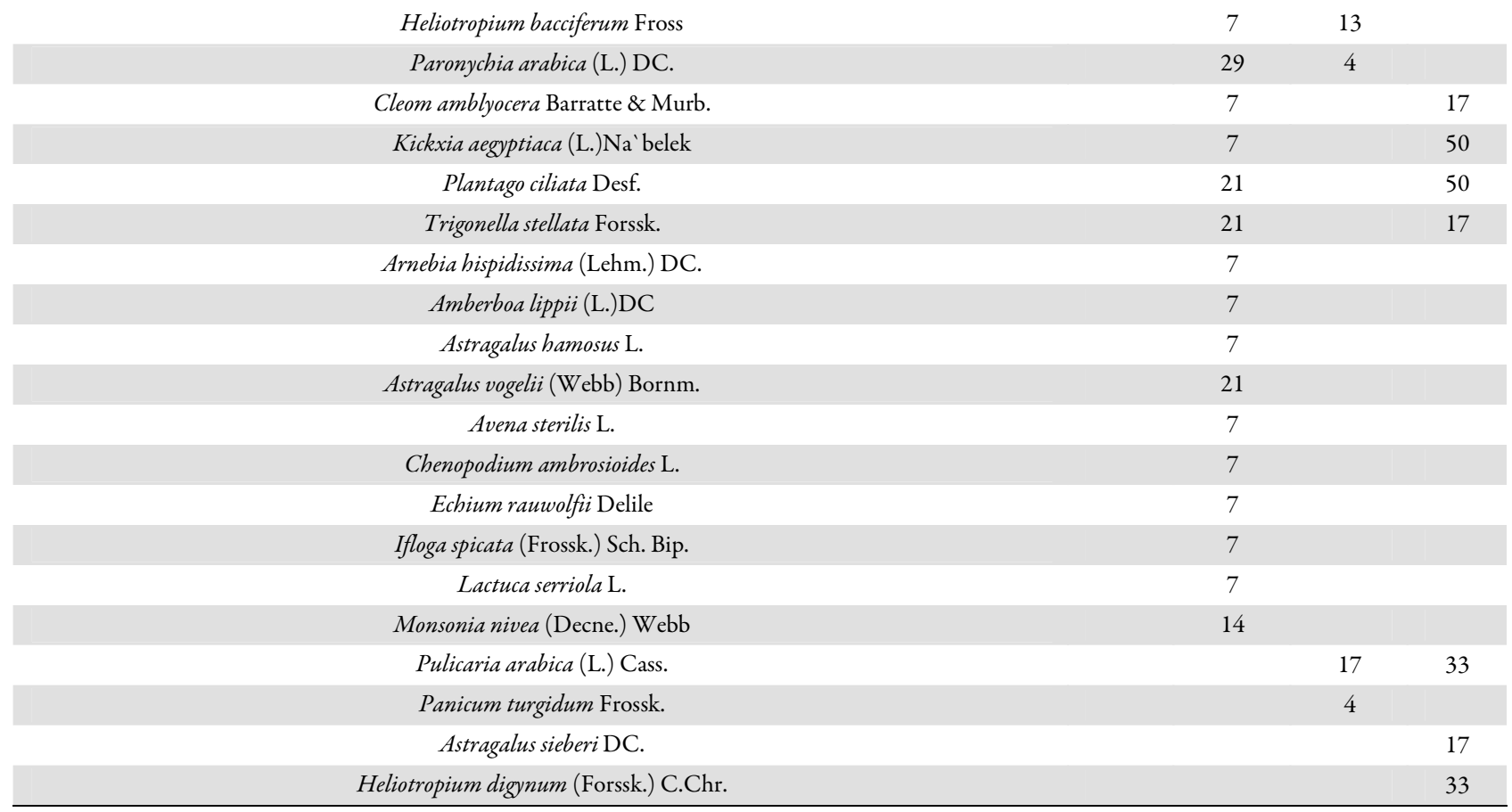

Fossati et al. (1998).

The phenological events of perennials are fairly constant regardless of the rainfall. This is because these plants depend on a permanent source of the underground water. The majority of perennial species behave similarly to each other in their phenology. Usually perennials sprouted in the end of the month of February and become leafy in March, flowered in April and produced fruits between April and July (Abd El-Rahman and Batanouny, 1959; El-Adawy, 2001; Salama et al., 2013).

Classification of the presence/absence data set of 66 species recorded in 50 stands using cluster analysis yielded four vegetation groups at level two of the hierarchy (Fig. 5; Tab. 2). Most of the groups (A) and (B) stands were confined to the Main trunk of Wadi El-Assuity, while those of groups (C) and (D) were belonging to the Wadi ElAssuity tributary (Wadi Habib). These groups are named after the first and second dominant species as follows: (A) Senecio glaucus-Zygophyllum coccineum, (B) Zilla spinosaZygophyllum coccineum, (C) Calligonum polygonoides, and (D) Artemisia judaica-Matthiola longipetala. Group B was the largest (14 stands) group, including 49 species, followed by Group A (6 stands, 39 species). Some species showed a certain degree of fidelity, e.g. Acacia nilotica, Achillea fragrantissima, Ammi magus, Calotropis procera. Chenopodium murale, Cynodon dactylon and Datura innoxia was confined to Group A; Arnebia hispidissima, Amberboa lippii, Astragalus hamosus, Astragalus vogelii, Avena sterilis, Chenopodium ambrosioides, Echium rauwolfii, Ifloga spicata, Lactuca serriola and Monsonia niveato to Group B; Panicum turgidum to Group C; and Astragalus sieberi and Heliotropium digynum to Group D. Sixteen species were recorded in all groups, including Bassia indica, Diplotaxis acris, Eremobium aegyptiacum, Matthiola longipetala, Trichodesma africanumas annuals and Cotula cinerea, Fagonia arabica, Launaea nudicaulis, Leptadenia pyrotechnica, Pulicaria undulata, Salsola imbricata, Senecio glaucus, Tamarix nilotica, Zilla spinosa, Zygophyllum coccineum, Artemisia judaica as woody perennials (Tab. 2).

In their detailed study on the plant communities in the vicinity of this study area, El-Sharkawi et al. (1982a) described three major community types. The first included Zilla spinosa, Zygophyllum coccineum, Schouwia thebaica, Zygophyllum simplex, Cotula cinerea, Salsola baryosma, Pulicaria undulata, Tribulus pentandrus, and Launaea capitata. Certainly, the identified vegetation group B belongs to these community type. Kassas and Girgis (1972) stated that the plant growth in WAdi Al-Assiuty and Wadi Habib differes in obvious relations to the size of the catchment area. They recognized also Zilla spinosa, Zygophyllum coccineum, and Leptadenia pyrotechnica community types among other communities recorded in the studied wadis.

\section{References}

Abd El-Ghani MM (1981). Preliminary studies on the vegetation of Bahariya Oasis-Egypt, Cairo Univ., MSc Diss. Abd El-Ghani MM (1998). Environmental correlates of species distribution in arid desert ecosystems of eastern Egypt. Journal of Arid Environment 38:297-313.

Abd El-Rahman AA, Batanouny KH (1959). The phenology of desert plants in relation to environment. Bull Inst $\mathrm{Du}$ Desert d'Egypt 9:11-19.

Abdel Wahab AM (1963). Autecological studies on Leptadenia pyrotechnica (Frossk.) Dence. Assiut Univ, MSc Diss.

Abdel-Razik MS (1980). A Study on Productivity and Nutrient Turn-Over of Some Common Plant Species in 
the Western Mediterranean Desert of Northern Egypt. Univ Alexandria, Alexandria, PhD Diss.

Abu Al-Izz MS (1971). Landforms of Egypt. The American University in Cairo Press, Cairo, Egypt, 281 p.

Batanouny KH (1973). Habitat features and vegetation of deserts and semi-deserts in Egypt. Vegetation 27:181-199.

Bornkamm R, Kehl H (1985). Pflanzengeographische zonen in der Marmarika (Nordwest-Agypten). Flora 176:141-151.

Boulos L (1995). Flora of Egypt, Checklist. Al Hadara Publishing, Cairo, Egypt, 283 p.

Boulos L (1999). Flora of Egypt, Vol. 1: AzollaceaeOxalidaceae: Al Hadara Publ., Cairo, 419 p.

Boulos L (2000). Flora of Egypt, Vol. 2: GeraniaceaeBoraginaceae: Al Hadara Publ., Cairo, 352 p.

Danin A, Orshan G (1990). The distribution of Raunkiaer life forms in Israel in relation to the environment. J Veg Sci 1:41-48.

El-Adawy HAA (2001). Habitats and plant species diversity along Katamiya-Ain 4-Sokhna Road. Botany department, Facult Sci, Helwan Univ. MSc. Diss.

El-Khatib AA (1993). Ecophysiological and palynological studies on the vegetation of the extreme arid part of Egypt. Botany Department, Facu Sci, Assiut Univ, PhD. Diss.

El-Sharkawi HM, Fayed AA, Salama FM (1982). Vegetation of inland desert wadis in Egypt. II. Wadi El-Matuli and Wadi El-Qarn. Feddes Repertorium 93:125-133.

El-Sharkawi HM, Fayed AA, Salama FM (1988). Vegetation of inland desert wadis in Egypt. IX. Eastern tributaries of lower Wadi Qena. Feddes Repertorium 99:489-495.

El-Sharkawi HM, Fayed AA, Salama, FM (1984).Vegetation of inland desert wadis in Egypt. VI. Wadi Qassab. Feddes Repertorium 95:561-570.

El-Sharkawi HM, Salama FM, Fayed AA (1982). Vegetation of inland desert wadis in Egypt.III. Wadi Gimal and wadi ElMiyah. Feddes Repertorium 93:135-145.

El-Sharkawi HM, Salama FM, Fayed AA (1987). Vegetation of inland desert wadis in Egypt. VIII. Wadi Kherit. Feddes Repertorium 98:543-547.

Estabrook GF, Winsor JA, Stephenson AG, Howe HF (1982). When are two phenological patterns different? Bot Gaz 143:374-378.

Fossati J, Pautou G, Peltier JP (1998). Wadi vegetation of the North-Eastern desert of Egypt. Feddes Repertorium 109:313-327.

Galal TM, Fahmy AG (2012). Plant diversity and community structure of Wadi Gimal protected area, Red Sea Coast of Egypt. African Journal of Ecology 50:266-276.

Girgis WA (1965). Studies on the plant ecology of eastern desert (Egypt), Facult Sci, Cairo Univ, Egypt. PhD. Diss.

Hassan AA (2003). Habitat and plant species diversity along the red sea coast in Egypt. Facult Sci, Cairo Univ, Egypt. MSc. Diss.

Hassan LM (1987). Studies on the flora of Eastern Desert, Egypt. Facult Sci, Cairo Univ. PhD. Diss.

Hassib M (1951). Distribution of plant communities in Egypt.
Bull Facult Sci, Univ Fouad I, Cairo, Egypt 29:59-261.

Henderson PA, Seaby RMH (1999). Community Analysis Package (CAP) version 1.2. Pisces Conservation Ltd. IRC House, UK.

Kassas M (1953a). Habitats and plant communities in the Egyptian deserts. I. Introduction. Journal of Ecology 40:342-351.

Kassas M (1953b). Habitats and plant communities in the Egyptian deserts. II. The features of a desert community. Journal of Ecology 41:248-256.

Kassas M (1955). Rainfall and vegetation belts in arid NE Africa. Plant Ecology. Proceedings of the Montpellier Symposium, UNESCO 5:49-77.

Kassas M, El-Abyad MS (1962). On the phytosociology of the desert vegetation of Egypt. Annals of Arid Zone 1:55-83.

Kassas M, Girgis WA (1964). Habitats and plant communities in the Egyptian deserts. V. The limestone plateau. Journal of Ecology 52:107-119.

Kassas M, Girgis WA (1965). Habitat and plant communities in the Egyptian desert. VI. The units of desert ecosystem. Journal of Ecology 53:719-729.

Kassas M, Girgis WA (1972). Studies on the ecology of the Eastern Desert of Egypt. The region between lat. 2730' N and lat. $25^{\circ} 30^{\prime} \mathrm{N}$. Bull de la Societe de Geographie d'Egypte 42:42-72.

Kassas M, Imam M (1954). Habitats and plant communities in the Egyptian deserts. III. The wadi bed ecosystem. Journal of Ecology 42:424-441.

Kemp PR, Gardetto PE (1982). Photosynthetic pathway types of evergreen rosette plants of the Chihuahuan desert. Oecologia 55:149-156.

Kürschner H (1986). A study of the vegetation of the Qurm Nature Reserve, Muscat area, Oman. Arab Gulf J Scientific Res 4:23-52.

Lee YN (1971). Patterns of flowering in selected floras of the World. J Korean Res Inst Better Living 6:41-52.

Migahid AM, Abdel Wahab AM, Batanouny KH (1972). Ecophysiological studies on desert plants. VII- Studied the water relations of Leptadenia pyroyechnic (Frossk.) Dence. growing in the Egyptian deserts. Oecologia 10:79-91.

Migahid AM, Batanouny KH, Zaki MAF (1971). Phytosociological and ecological study of a sector in the Mediterranean coastal region in Egypt. Vegetatio 23:113134.

Montasir AH (1938). Egyptian soil structure in relation to plants. Bull Facult Sci, Fouad I Univ, Cairo, Egypt 29:1-52.

Orlóci L (1978). Multivariate Analysis in Vegetation Research, 2nd ed. W. Junk B.V. Publishers, The Hague, Boston.

Orshan G (1986). The desert of the Middle East, p1-28. In: Evenari M, Noy-Meir I, Good DW (Eds.). Ecosystems of the world, 12b, Hot Desert and Arid Shrublands. El-Sevier, Amsterdam.

Pignatti E, Pignatti S (1989). Life forms distribution and phytogeographical affinities of the Canarian flora. Flora 183:87-95. 
206

Ralhan PK, Khanna RK, Singh SP, Singh JS (1985). Phenological characteristics of the tree layer of Kumaun Himalayan forests. Vegetatio 60:91-101.

Raunkiaer C (1937). The Life Forms of Plants and Statistical Plant Geography. Clarendon Press, Oxford, 104 p.

Said R (1962). The geology of Egypt, Elsevier, Amsterdam, 377 p.

Salama FM, Abd El-Ghani MM, El-Tayeh NA (2013). Vegetation and soil relationships in the inland wadi ecosystem of central Eastern Desert, Egypt. Turkish Journal of Botany 37:489-498.

Salama FM, Ahmed MK, El-Tayeh NA, Hammad SA (2012). Vegetation analysis, phenological patterns and chorological affinities in Wadi Qena, Eastern Desert, Egypt. African Journal of Ecology 50:193-204.

Salama FM, El-Naggar SM (1991). Phytosociology of wadi system west of Qusseir province. 102:453-468.

Salama FM, Fayed AA (1989). Phytosociological studies along the Idfu-Marsa Alam road. Feddes Repertorium 100:191195.
Salama FM, Fayed AA (1990). Phytosociological study on the deltaic part and the principal channel of wadi Qena, Egypt. Feddes Repertorium 101:89-95.

Schweinfurth G (1901). The flora of the desert surrounding Helwan, In: May WP (Eds.). Helwan and the Egyptian desert, London.

Sheded MG (1992). Environment and vegetation in the South Eastern Desert, Egypt. Facult Sci, Assiut Univ. PhD. Diss.

Täckholm V (1974). Student's Flora of Egypt, 2nd ed. Cairo University Press, Cairo, Egypt. 888 p.

Zohary M (1966). Flora Palaestina. The Israel Academy of Sciences of Humanities.

Zohary M (1972). Flora Palaestina. Part II. The Israeal Academy of Science and Humanities, Goldberg's Press, Jerusalem, $489 \mathrm{p}$.

Zohary M (1973). Geobotanical Foundation of the Middle East. Volumes 1-2. Gustav Fischer Vertlag, Stuttgart, 739 p. 